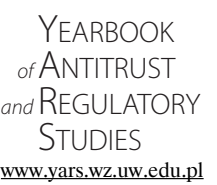

Peer-reviewed scientific periodical, focusing on legal and economic issues of antitrust and regulation. Creative Commons Attribution-No Derivative Works 3.0 Poland License.

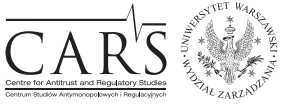

Centre for Antitrust and Regulatory Studies, University of Warsaw, Faculty of Management www.cars.wZ.uw.edu.pl

\title{
Europeanisation of the Polish Leniency Programme
}

\author{
by
}

\author{
Paulina Korycińska-Rządca*
}

\section{CONTENTS}

I. Introduction

II. Polish leniency programme and the ECN Model Leniency Programme (spontaneous harmonisation)

III. Polish leniency programme and EU legal acts (legislative harmonisation)

IV. Impact of EU jurisprudence on the application of the legal provisions on the Polish leniency programme by the national authorities (judicial harmonisation)

V. Conclusions

\section{Abstract}

Leniency programmes in competition law make it possible to grant immunity from fines, or a reduction of any fine that would otherwise have been imposed on an undertaking who was a party to an unlawful agreement restricting competition. This immunity or fine reduction is granted as a reward for the cooperation with the competition authority and the provision of evidence of an unlawful agreement restricting competition. Legal rules regarding the application of leniency programmes have been introduced at the EU level as well as in the national legislations of numerous countries, including Polish law. The author makes an attempt to establish the degree to which the Polish leniency programme is an effect of the impact of EU law or the application of law within the EU (for instance, by its institutions). The analysis has been made on three levels. Examined first was the degree to which the Polish leniency programme is a result of spontaneous harmonisation. Second,

* Assistant at the Department of Public Economic Law at the Faculty of Law at the University of Białystok, Poland; attorney-at-law in Kancelaria Radców Prawnych Bieluk i Partnerzy; ORCID identifier 0000-0002-6177-7409; e-mail: p.korycinska@gmail.com. Article received: 30 May 2018; accepted: 30 September 2018. 
the impact of legislative harmonisation in the area of leniency programmes was taken into consideration. Finally, it was verified whether those Polish authorities that apply Polish competition law are inspired by judgements issued by EU courts in cases regarding leniency programmes.

\section{Résumé}

Les programmes de clémence prévus par le droit de la concurrence permettent d'accorder une immunité d'amende ou une réduction de toute amende qui aurait autrement été infligée à une entreprise partie à un accord illégal restreignant la concurrence. Cette immunité ou réduction d'amende est accordée à titre de récompense pour la coopération avec l'autorité de la concurrence et la fourniture de la preuve d'un accord illégal restreignant la concurrence. Les règles juridiques relatives à l'application des programmes de clémence ont été mis en place au niveau de l'UE, ainsi que dans les législations nationales de nombreux pays, y compris le droit polonais. Lauteur tente de déterminer dans quelle mesure le programme de clémence polonais est un effet de l'impact du droit de l'UE ou de l'application du droit au sein de l'UE (par exemple, par ses institutions). Lanalyse a été faite à trois niveaux. Tout d'abord l'auteur examine dans quelle mesure le programme de clémence polonais résultait d'une harmonisation spontanée. Après, l'impact de l'harmonisation des législations dans le domaine des programmes de clémence a été prise en considération. Enfin, il a été vérifié si les autorités polonaises qui appliquent le droit de la concurrence polonais s'inspirent des décisions rendues par les tribunaux de l'Union européenne dans des affaires concernant des programmes de clémence.

Key words: leniency programme; harmonisation; spontaneous harmonisation; legislative harmonisation; judicial harmonisation; competition law.

JEL: K21

\section{Introduction}

Agreements restricting competition, especially those which are concluded between entities operating at the same level of trade, usually have a negative impact on competition on the relevant market (see inter alia: Banasiński and Piontek, 2009, p. 180; Frenz, 2016, p. 551; Stawicki, 2016, p. 211). Therefore, counteracting and combating them is particularly important for ensuring the proper functioning of the economy. It was indicated in a document entitled 'Competition and consumer protection policies' issued in 2015, that one of the principles of the Polish national competition authority, namely the President 
of the Office for the Competition and Consumer Protection (hereinafter; UOKiK President), is to increase the effectiveness of combating agreements restricting competition, in particular cartels. ${ }^{1}$ Due to the fact that agreements restricting competition most often are concluded and kept secret by their parties, detection and combating these violations by competition authorities is difficult.

Undoubtedly there are difficulties in disclosing agreements restricting competition. Due to that fact, leniency programmes are being implemented all over the world in order to induce entities that violated the prohibition of competition-restricting agreements to cooperate with competition authorities in exchange for more lenient treatment, in the form of immunity from fines or a reduction of any fine which would otherwise have been imposed on a participant in an agreement restricting competition.

The first country that has decided to introduce such regulations into its antitrust law was the United States of America. ${ }^{2}$ The American solution, however, concerned only the mitigation of criminal sanctions provided for violations of antitrust law. Similar regulations to those introduced into American antitrust law have also been adopted within the European Union (hereinafter; EU). It is worth noting that contrary to the solution adopted in American law, where the cartel prohibition is enforced not only with fines on companies but also with imprisonment of individuals, the European Commission and the competition authorities of most EU Member States can currently only impose fines on undertakings (see: Wils, 2007, p. 238-241). Therefore, the leniency programmes adopted within the EU include the mitigation of sanctions that are not of a criminal law nature (Article 23 paragraph 5 of Council Regulation (EC) No 1/2003 of 16 December 2002 on the implementation of the rules on competition laid down in Articles 81 and 82 of the Treaty $\left.^{3}\right){ }^{4}$

In September 2006, the European Competition Network (hereinafter; ECN), comprised of the European Commission and the national competition

${ }^{1}$ See: Competition and consumer protection policies, Warsaw 2015, p. 30 et seq. Polish version available at: https://www.uokik.gov.pl/download.php?plik=16694 (16.05.2018). Not available in English.

${ }^{2}$ It is considered that the contemporary practice of leniency in antitrust enforcement started in 1978 by the adoption by the US Department of Justice of its first Corporate Leniency Policy (see: Wils, 2007, p. 213-214).

3 OJ L 1, 4.1.2003, p. 1-25 as amended (hereinafter; Regulation No 1/2003).

${ }^{4}$ Despite the fact that Article 23 (5) of Regulation No 1/2003 expressly indicates such classification of those sanctions, there have been voices questioning this character indicating inter alia that the fines reach an amount that is rather indicative of criminal law (see more: Franz, 2016, p. 979). In Polish literature, see amongst others: Król-Bogomilska, 2013, p. 466; Piszcz, 2013, p. 29; Martyniszyn and Bernatt, 2015, p. 9; Bernatt and Turno, 2015, p. 88). 
authorities of all EU Member States, endorsed its Model Leniency Programme. ${ }^{5}$ The model was subsequently amended in November $2012 .{ }^{6}$ This document is of a soft law nature, which means that it is not compulsory to implement the rules set out in it into national legal orders. Nevertheless, the ECN Model Leniency Programme contains a commitment of entities creating the ECN to use their best efforts, within the limits of their competence, to align their respective programmes with the ECN Model Leniency Programme. ${ }^{7}$ In fact leniency programmes exist in all EU Member States, with the exception of Malta, which has started working on the introduction of such a solution but has not implemented it yet. ${ }^{8} \mathrm{~A}$ leniency programme exists also in proceedings before the European Commission, where it is governed by the Commission Notice on immunity from fines and reduction of fines in cartel cases. ${ }^{9}$

It is believed that leniency programmes are the most effective tool to combat agreements restricting competition, especially cartels, that is, agreements concluded between entities operating at the same level of trade (competitors) (Hammond, 2004, p. 2; see also: Jurkowska-Gomułka, 2015, p. 69), by significantly increasing the chances of competition authorities to obtain evidence necessary to reveal and prove the infringement (Turno, 2013, p. 23-45 and p. 291-304).

Actions which infringe the prohibition of competition-restricting agreements often have effects on the territory of more than one EU Member State. Therefore, any differences between the leniency programmes applicable in different EU Member States may weaken the applicants' incentives to apply for leniency. The necessity to harmonize national leniency programmes due to that factor was indicated in the proposal for a directive of the European Parliament and of the Council to empower the competition authorities of the Member States to be more effective enforcers and to ensure the proper functioning of the internal market, which was presented on 22 March 2017. ${ }^{10}$ In motive 10 of the proposal of this directive, it was clearly expressed that 'Companies will only come clean about secret cartels in which they have participated if they have sufficient legal certainty about whether they will benefit from immunity from fines'. In other words, leniency programmes may

5 ECN Model Leniency Programme. English version available at: http://ec.europa.eu/ competition/ecn/model_leniency_en.pdf (16.05.2018).

6 ECN Model Leniency Programme (As revised in November 2012). English version available at: http://ec.europa.eu/competition/ecn/mlp_revised_2012_en.pdf (16.05.2018). Hereinafter referred as the 'ECN Model Leniency Programme'.

7 ECN Model Leniency Programme, p. 1.

8 See: https://iclg.com/practice-areas/cartels-and-leniency-laws-and-regulations/malta (16.05.2018).

9 2006/C 298/11.

${ }^{10} \operatorname{COM}(2017) 142$ final. 
become an effective weapon against cartels with an international element only if the national leniency programmes are convergent. Only then, the entity submitting a leniency application will have certainty of the rules in force in different legal orders, including a guarantee that the conditions and rules for applying for leniency are analogous. Any differences in leniency programmes may negatively affect the interest of the potential applicant (the applicant who is not sure whether it can avoid penalty in all countries may not be willing to disclose the infringement and apply for leniency).

The first legal rules governing the leniency programme were introduced into Polish competition law by the Act of 16 April 2004 amending the Act on competition and consumer protection and certain other acts, ${ }^{11}$ which amended the Act of 15 December 2000 on competition protection and consumers $^{12}$ (hereinafter; ACCP 2000) as of 1 May 2004. The rules governing the leniency programme in this act were modelled on solutions provided for in the Commission notice on immunity from fines and reduction of fines in cartel cases of 13 February $2002 .{ }^{13}$ This realisation was explicitly stated in the explanatory notes attached to the draft Act amending the Act on competition and consumer protection and amending some other acts. ${ }^{14}$ The solutions introduced by the above legal act were transferred into the Act of 16 February 2007 on competition and consumer protection ${ }^{15}$ (hereinafter; ACCP). At that time, the general principles of the leniency programme were adopted in ACCP; detailed procedural solutions were set out in the regulation of the Council of Ministers of 26 January 2009 on the procedure for undertaking to apply to the President of the Office for Competition and Consumer Protection for immunity from fine or the reduction of fine. ${ }^{16}$ However, the sources of the Polish legislator's inspiration in creating the legal framework of this legal institution were not indicated in the explanatory notes to the draft of the ACCP. Only a brief reference was made to the previously binding ACCP $2000 .{ }^{17}$ The Polish leniency programme was substantially amended by the Act of 10 June 2014 amending the Act on Competition and Consumer Protection

11 Journal of Laws 2004, no. 93, item 891.

12 Consolidated text: Journal of Laws 2005, no. 244, item 2080.

13 Official Journal C 045, 19.02.2002, p. 0003-0005.

14 Explanatory notes to the draft Act amending the Act on competition and consumer protection and amending some other acts (Sejm paper no. 2561), p. 4. Polish version available at: http://orka.sejm.gov.pl/proc4.nsf/opisy/2561.htm (16.05.2018). Not available in English.

15 Consolidated text: Journal of Laws 2018, item 798 as amended.

16 Journal of Laws 2009, no. 20, item 109.

17 Explanatory notes to the draft Act on competition and consumer protection together with draft executive acts (Sejm paper no. 1110), p. 26. Polish version available at: http://orka.sejm. gov.pl/proc5.nsf/opisy/1110.htm (16.05.2018). Not available in English. 
and the Civil Procedure Code ${ }^{18}$ (hereinafter; Amendment Act of 2014), which entered into force on 18 January 2015 . The explanatory notes of the draft amendment act indicates that at least some of the solutions proposed by the authors of the draft act were inspired by, or at least referred to, the ECN Model Leniency Programme. ${ }^{19}$

In Poland, the leniency programme has not achieved the expected success (see inter alia: Turno in: Stawicki and Stawicki, p. 1482). The number of leniency applications is relatively low. In the years 2004-2016, only 64 applications were submitted under this programme (one of them under the leniency plus programme $\left.{ }^{20}\right) .{ }^{21}$ The greatest number of 16 applications was received by the UOKiK President in 2012. In 2015 there were only two such submissions. Therefore, the question arises about what determines the small interest of undertakings in this legal institution. Can the lack of harmonisation of Polish national rules with analogous programmes in force in other EU Member States be the reason for that?

The subject of the analysis in this article is the Polish leniency programme. The considerations contained in this paper are aimed at verifying the following research thesis: despite the fact that EU legislature has not used legislative harmonisation for leniency programmes yet, the Polish leniency programme is largely inspired by the Model Leniency Programme endorsed within the ECN. It can, therefore, be said that the shape of the rules governing the Polish leniency programme is a manifestation of the Europeanisation of competition law made through spontaneous harmonisation. The Model Leniency Programme, adopted under the cooperation of competition authorities associated in the ECN, became a strong inspiration for national legislators, including the Polish one. However, the method of minimum harmonisation ${ }^{22}$ proposed by the ECN has resulted in a situation where the Polish leniency programme goes beyond the model solution. Due to the application of this kind of approximation of laws, differences between the various systems could

18 Journal of Laws 2014, item 945.

19 See: explanatory notes to the draft Act amending the Act on competition and consumer protection and the Code of Civil Procedure (Sejm paper no. 1703), p. 30. Polish version available at: http://www.sejm.gov.pl/Sejm7.nsf/druk.xsp?nr=1703 (16.05.2018). Not available in English.

${ }^{20}$ Regarding the rules governing the leniency plus programme see remarks in part II of this article.

21 Sprawozdanie z dziatalności UOKiK 2016 (Report on the operations of UOKiK 2016), Warsaw 2017, p. 36. Polish version available at: https://www.uokik.gov.pl/sprawozdania_z_ dzialalnosci_urzedu.php (16.05.2018). Not available in English.

22 In section 3 of the ECN Model Leniency Programme, it was directly indicated that 'The ECN Model Programme does not prevent a CA [Competition Authority] from adopting a more favourable approach towards applicants within its programme'. See: ECN Model Leniency Programme, section 3, p. 1. 
not be avoided. As a consequence, potential applicants cannot be sure that the rationale for this kind of programmes and procedures in different EU Member States is the same.

The purpose of this article is to find an answer to the question whether, and if so by which mechanisms the Polish leniency programme is subjected to the process of Europeanisation. However, answering this question would not be possible without establishing:

1) Whether, and if so, to what extent is the Polish leniency programme harmonised with the ECN Model Leniency Programme?

2) Whether, and if so, to what extent has EU legislature undertaken activities aimed at harmonising national leniency programmes by means of legislative harmonisation?

3) Whether, and if so, to what extent the Polish competition authority and courts, while applying the rules governing the Polish leniency programme, follow the jurisprudence of EU courts regarding leniency programmes and refer to these judgements in their decisions?

The answers to the above questions should make it possible to verify whether the shape of the Polish leniency programme is a result of spontaneous, legislative or jurisprudential harmonisation, ${ }^{23}$ and if so, to what extent each of these methods of harmonisation has influenced the national legal framework.

In this research, the author mainly used the dogmatic method of analyzing the provisions contained in legal acts regulating the Polish leniency programme and the content of soft law documents related to the development of the ECN Model Leniency Programme. References were also made to views expressed in legal literature. In this paper, the comparative method was also used in order to identify the extent to which Polish regulation of the leniency programme is Europeanised. It was also important to analyze the application practice of rules governing the leniency programme by the UOKiK President and Polish courts.

\section{Polish leniency programme and the ECN Model Leniency Programme (spontaneous harmonisation)}

The analysis of the legal regulations concerning the Polish leniency programme leads to the conclusion that the national legislator decided to transfer, to a significant degree, the solutions proposed in the ECN Model

${ }^{23}$ In this article, the author has followed the methods of spontaneous, legislative and judicial harmonisation of competition law which have been distinguished by K. Kowalik-Bańczyk. See: Kowalik-Bańczyk, 2014, p. 141-159. 
Leniency Programme into the Polish legal order. However, some differences can be seen between the Polish and the model solution.

The basic difference between the rules governing the Polish leniency programme and the ECN Model Leniency Programme is already visible at the stage of comparing the scope ratione personae of these programmes. The Polish regulations encompass any undertaking ${ }^{24}$ who has infringed the prohibition of competition-restricting agreements specified in Article 6 paragraph 1 of the ACCP or Article 101(1) of the Treaty on the Functioning of the European Union (hereinafter; TFEU). In other words, it is irrelevant whether the prohibited agreement was concluded between entities operating at the same trading level (horizontal agreement) or between entities operating at different trading levels (Rumak and Sitarek, 2009, p. 102-103). By contrast, in accordance with the assumptions of the ECN Model Leniency Programme, such programmes shall be limited only to secret cartels, that is, the agreements concluded between undertakings operating at the same trading level (competitors). ${ }^{25}$ The only exception from this rule is the possibility to include also cartels with vertical elements, that is, hub and spoke agreements (for example: an agreement concluded between a producer and several distributors). It was explained in the Explanatory Notes to the ECN Model Leniency Programme that 'Other types of restriction such as vertical agreements and horizontal restrictions other than cartels are normally less difficult to detect and/or investigate and therefore do not justify being dealt with under a leniency programme'. ${ }^{26}$ It is also worth noting that in most EU Member States leniency programmes are applicable only to horizontal agreements, ${ }^{27}$ including additionally hub and spoke agreements.

This means that the scope of the Polish leniency programme is wider than the scope of most European leniency programs (see: Rumak and Sitarek, 2009, p. 102-103), ${ }^{28}$ including the ECN Model Leniency Programme and the

24 The beneficiary of the leniency programme in Poland may also be a managing person within the meaning of Article 4 subparagraph 3a of the ACCP, who in connection with performing his function at the time of the ascertained infringement of the prohibitions concerned - intentionally allowed, through action or omission, infringement by the undertaking of prohibitions referred to in Article 6 paragraph 1 subparagraphs 1-6 of the ACCP or in Article 101 paragraph 1 subparagraphs a-e of the Treaty on the Functioning of the European Union.

25 ECN Model Leniency Programme, section 4, p. 2.

${ }^{26}$ ECN Model Leniency Programme Explanatory Notes, section 14, p. 11.

27 Similarly as it is in the case of the leniency programme applied by the European Commission. See section 8 of the Commission Notice on Immunity from fines and reduction of fines in cartel cases.

28 See: ECN Model Programme: Report on Assessment of the State of Convergence, issued by ECN on 13 October 2013, where there was indicated that only Polish, Swedish, Romanian and Finnish leniency programmes among the ECN members had a wide scope of application. 
leniency programme applied by the European Commission. ${ }^{29}$ The inclusion of all agreements restricting competition in the Polish leniency programme, regardless of their nature, has been criticized by some of the commentators (see: Turno, 2013, p. 460-465 and the literature indicated therein; also see: Molski, 2009, p. 71; Molski in: Skoczny, 2014, p. 1407; differently: Sołtysiński in: Banasiński, 2004, p. 41). Some of authors have also found that this approach is incompatible with the principles of necessity and of the effective application of Article 101 TFEU (Sitarek, 2014, p. 210). At the same time, however, it is indicated that the inclusion of hub and spoke agreements into the Polish leniency programme should be assessed positively (Turno, 2013, p. 461; Molski in: Skoczny, 2014, p. 1408).

Both the Polish leniency programme and the ECN Model Leniency Programme provide for two forms of alleviating responsibility for the beneficiaries of the programme: immunity from fines and the reduction of fines, ${ }^{30}$ but the rules for obtaining them are not identical.

In the case of immunity from fines, the differences between the Polish leniency programme and the ECN Model Leniency Programme are already visible at the stage of determining the requirements for obtaining this form of a mitigation of responsibility. In the Polish leniency programme, full immunity from fine is granted to an undertaking which has entered into an agreement referred to in Article 6 paragraph 1 of the ACCP or in Article 101 TFEU and fulfilled all of the following requirements:

1) it was the first of the participants of the agreement to submit an application meeting the requirements specified in Article 113a paragraph 2 of the ACCP and also not to disclose the intention to submit an application; cooperated fully with the UOKiK President from the time of submitting the application ${ }^{31}$; and ceased to participate in the agreement before submitting the application or immediately after submitting the application;

2) it has submitted evidence sufficient to institute antimonopoly proceedings $^{32}$, or information enabling the UOKiK President to

Available at: http://ec.europa.eu/competition/ecn/model_leniency_programme.pdf (16.05.2018). On the changes in the legal orders of those countries in this regard see: Sitarek, 2014, p. 209.

${ }^{29}$ Due to this discrepancy, it is emphasized that the Polish leniency programme is significantly different from the EU programme (Piszcz, 2015, p. 93).

${ }^{30}$ Article 113a paragraph 1 of the ACCP and sections 5, 7 and 9 of the ECN Model Leniency Programme.

${ }^{31}$ It is emphasized that the applicant should perform an active role and provide information and evidence to the UOKiK President without waiting for calls from the authority (Banasiński and Piontek, 2009, p. 1005; Molski in: Skoczny, 2014, p. 1412).

32 Under Polish law, the name 'antimonopoly proceedings' refers to full competition law proceedings. 
obtain such evidence, or if the application was submitted following the institution of antimonopoly proceedings - evidence that will significantly contribute to the issuance of the decision declaring a practice as restricting competition, or - upon the request of the UOKiK President - information making it possible to obtain such evidence, provided that the UOKiK President was not in possession of such information or evidence at that time;

3) it has not encouraged other undertakings to participate in the agreement. ${ }^{33}$

Comparing these requirements with the requirements established in the ECN Model Leniency Programme, the two areas in which discrepancies appear should be pointed out.

First of all, the Polish leniency programme makes it possible to obtain immunity from fine not only if the applicant provides the UOKiK President with evidence sufficient to initiate antimonopoly proceedings or significantly contributes to the decision declaring a practice as restricting competition, but also when the applicant provides only information enabling the UOKiK President to obtain such evidence (Article 113b subparagraph 1 of the ACCP) (see: Molski in: Skoczny 2014, p. 1416). By contrast, the ECN Model Leniency Programme - similarly to the leniency programme applied by the European Commission $^{34}$ - establishes the requirement to provide the competition authority with evidence..$^{35}$ Thus, according to the ECN Model Leniency Programme, only providing information on the evidence would not be sufficient to obtain immunity from fines. Within this requirement, the Polish leniency programme establishes more stringent requirements in this respect than the ECN Model Leniency Programme.

Secondly, the ECN Model Leniency Programme - similarly to the leniency programme applied by the European Commission ${ }^{36}-$ excludes from the subjective scope of this programme undertakings who coerced other entrepreneurs to participate in the cartel. ${ }^{37}$ By contrast, the Polish

33 Article $113 \mathrm{~b}$ of the ACCP.

${ }^{34}$ Section 11 of the Commission Notice on Immunity from fines and reduction of fines in cartel cases.

35 ECN Model Leniency Programme, sections 5 and 7, p. 2-3.

36 Section 13 of the Commission Notice on Immunity from fines and reduction of fines in cartel cases. It is also worth pointing out that in the Polish language version of this notice the term 'coerce' has been erroneously translated as 'encourage', and therefore the requirement in the Polish leniency programme to not encourage other entrepreneurs to participate in the agreement is in line with the Polish language version of the notice.

37 In accordance with section 8 of the ECN Model Leniency Programme: 'An undertaking which took steps to coerce another undertaking to participate in the cartel will not be eligible for immunity from fines under the programme', ECN Model Leniency Programme, section 8, p. 3. 
leniency programme excludes from immunity from fines any undertaking who encouraged (in Polish: naktaniać) other undertakings to participate in the agreement. The use of the term 'not encouraged other undertaking' ${ }^{38}$ by the Polish legislator resulted in the exclusion from immunity from fines of a wider range of undertakings, as 'encouraging' is a much lighter form than 'coercing' (Piszcz, 2015b, p. 50). It is also rightly pointed out that meeting this requirement may be extremely difficult, because sometimes even a passive role of the undertaking, limited to the sole participation in the agreement, may be sufficient to encourage other undertaking (see: Turno in: Stawicki and Stawicki, 2016, p. 1519). As a result, the Polish leniency programme puts the applicant in a more difficult situation. This may be the reason why the Polish leniency programme is not widely applied (see also: Turno, 2013, p. 512-215; Molski in: Skoczny, 2014, p. 1418-1419).

Within the remaining scope, the requirements for immunity from fines set out in the rules governing the Polish leniency programme are similar to those set out in the ECN Model Leniency Programme.

Regarding the second form of mitigating liability, namely reduction of fines, the Polish leniency programme and the ECN Model Leniency Programme determine convergent grounds, requiring the applicant: to submit a request to reduce the fine; not to disclose the intention to submit a leniency application; to cooperate genuinely, fully and on a continuous basis from the time of its application with the competition authority until the conclusion of the case, including not destroying, falsifying or concealing relevant information or evidence related to the matter; to end its involvement in the alleged agreement (as a rule immediately following the application); and to submit evidence relevant to the case which was not in the possession of the competition authority. ${ }^{39}$

There are, however, significant differences relating to the principles of fine reductions. In this regard the ECN Model Leniency Programme is limited only to indicating that the determination of the level of reduction of the fine should be made taking into account the time at which the evidence was submitted and the competition authority's assessment of the overall value added to its case by that evidence. The only restriction on the fine reduction is the stipulation that the fine imposed on the undertaking who submitted the application under the leniency programme after the competition authority initiated the proceedings shall not exceed $50 \%$ of the fine which would otherwise have been imposed. ${ }^{40}$

38 Regarding the interpretation problems of this concept, see: Molski in: Skoczny, 2014, p. 1417-1418; Turno in: Stawicki and Stawicki, 2016, p. 1519.

39 Article $113 \mathrm{c}$ paragraph 1 of the ACCP and sections 10 and 13 ECN Model Leniency Programme.

40 ECN Model Leniency Programme, section 11, p. 4. 
As it is explained in the Explanatory Notes to the ECN Model Leniency Programme, this limitation is aimed at ensuring that there is a significant difference between immunity from fines and reductions of fines. In that case, the application for immunity becomes significantly more attractive. ${ }^{41}$ The ECN Model Leniency Programme does not introduce any other rules that should be followed by the competition authority while determining the specific level of fine reductions.

The legal regulations regarding the Polish leniency programme contain more detailed rules for the reduction of fines. In accordance with Article 113c paragraph 2 of the ACCP, the level of the fine reduction depends on the order in which the undertaking meets the conditions for a reduction of the fine: (1) in the case of the first undertaking to fulfil the conditions, the UOKiK President shall impose a fine reduced of $30 \%-50 \%$ compared to the fine that would have been imposed upon the undertaking had the undertaking not submitted the leniency application; (2) in the case of an undertaking who is the second to fulfil the conditions - reduction of $20 \%-30 \%$ compared to the fine that would have been imposed upon the undertaking had the undertaking not submitted the leniency application; and (3) in the case of other undertakings which have fulfilled the conditions - a maximum of a $20 \%$ fine reduction. The levels of fine reductions adopted by the Polish legislator are analogous to those applied by the European Commission. ${ }^{42}$ Thus, the Polish leniency programme, on the one hand, gives less of a margin of discretion to the UOKiK President when determining the level of a fine reduction than the ECN Model Leniency Programme but, on the other, it is more transparent for the undertaking applying for leniency (Molski in: Skoczny, 2014, p. 1423).

As regards the procedure for leniency, the Polish leniency programme and the ECN Model Leniency Programme provide for similar solutions. In this respect, particular attention should be paid to three areas.

The first concerns the rules related to the confirmation by the competition authority of the moment of filing a leniency application. In accordance with the rules governing the Polish leniency programme, the UOKiK President shall confirm the date and time of filing of the application. ${ }^{43}$ The ECN Model Leniency Programme states that the provision of date and time is made upon

41 ECN Model Leniency Programme Explanatory Notes, section 24, p. 13.

42 Section 26 of the Commission Notice on Immunity from fines and reduction of fines in cartel cases.

43 Article 113a paragraph 4 of the ACCP. It is assumed that confirmation of the date and time of submitting the application in the case of oral submissions should be made in the minutes of entering an oral application, applications submitted in writing should take place on the copy of the application intended for the competition authority and on the applicant's copy, and in the case of applications submitted in the form of a paper sent by post or electronic mail, confirmation of the date and time of submitting the application should be made in the first 
request. ${ }^{44}$ Considering that in both programmes the competition authority is obliged to immediately inform the applicant that the conditions for immunity from fines or the reduction of the amount of the fines have been met, the lack of the obligation to confirm the date and time of filing the application ex officio in the ECN Model Leniency Programme is of secondary importance from the applicant's point of view. That is so especially because in the case of such a request, the ECN Model Leniency Programme obliges the competition authority to confirm this information.

The second noteworthy procedural issue is applying for a 'marker'. The ECN Model Leniency Programme provides for the possibility of applying for a marker in order to protect a given applicant's place in the queue for a set period of time, which allows that applicant to gather necessary information and evidence in order to meet the relevant evidential threshold for immunity. ${ }^{45}$ The Polish equivalent of the application for a marker is a leniency application in a shortened form. The ECN Model Leniency Programme indicates that the application for a marker - similarly to the regular application - may concern only cartels or hub and spoke agreements; in the Polish leniency programme such limitation does not exist. ${ }^{46}$ The rules contained in the ECN Model Leniency Programme state that if the applicant perfects the marker within the set period, the information and evidence provided will be deemed to have been submitted on the date when the marker was granted. Simultaneously, however, the model programme makes a reservation that the competition authority has discretion as to whether to grant a marker. ${ }^{47}$ As a result, the applicant who decides to apply for a marker cannot be sure that its place in the queue will indeed be protected, even if the application for a marker meets all the requirements established in the ECN Model Leniency Programme. By so doing, the model leniency programme encourages applicants to file complete, regular leniency applications, because the later protect the given place of the undertaking in the queue. Giving a competition authority the power to decide freely about granting a marker should convince the applicant to apply for a marker only as a last resort.

A slightly different solution in this respect has been implemented by the Polish legislator. In Article 113e paragraph 2 of the ACCP, it is stated that the UOKiK President shall promptly, once an undertaking has submitted a leniency application, specify the scope of the information or evidence

letter of the UOKiK President (see: Turno, 2013, p. 600; Turno in: Stawicki and Stawicki, 2016, p. 1500; Molski in: Skoczny, 2014, p. 1411).

44 ECN Model Leniency Programme, section 15, p. 5.

45 ECN Model Leniency Programme, section 16, p. 5.

${ }^{46}$ Article 113e paragraph 1 of the ACCP.

47 ECN Model Leniency Programme, section 17, p. 5. 
that must be submitted and time limit for its submission. Thus, the UOKiK President has not been equipped with the competence to refuse to protect a place in the queue for an undertaking submitting a leniency application in a shortened form (Turno in: Stawicki and Stawicki, 2016, p. 1534). ${ }^{48}$ Only if the undertaking fails to submit the additional information and evidence within the specified time limit would its application not being reviewed (Article 113e paragraph 4 of the ACCP). ${ }^{49}$ This basically means that the Polish solution regarding the possibility of submitting the leniency application in a shortened form is more favourable for the applicant than the one provided for in the ECN Model Leniency Programme.

The Polish legal framework not only provides for the possibility of submitting a leniency application in a shortened form with respect to a wider scope of competition-restricting agreements, but it also does not equip the UOKiK President with the discretion to refuse to grant a place in the queue. Especially the latter difference may result in a decision to apply for leniency in a shortened form as the preparation of the shortened application requires less work and time. Additionally, if the applicant manages to perfect the application within the specified time limit, the shortened application will have the same effect as submitting a regular leniency application straight away. It is also worth noting that the assumptions of the leniency application in a shortened form provided for in the ECN Model Leniency Programme reveal that the main purpose of this application is to grant undertakings immunity from fines. Only when the competition authority informs the undertaking that applied for a marker that their application for immunity is rejected, may the undertaking consider submitting an application for a reduction of the fine..$^{50}$ The Polish legal framework does not provide for such a solution, which means that the undertaking, by submitting the leniency application in a shortened form may immediately apply for immunity from fines or for a fine reduction. Then, if the conditions for immunity from fines are not met, the date of submitting the leniency application in a shortened form and perfected within the time set by the UOKiK President will determine the place in the queue of that undertaking when deciding on the level of the fine reduction.

48 Similar view has been expressed by E. Modzelewska-Wąchal who indicated that the UOKiK President after the receipt of a summary leniency application is obliged to inform the undertaking of the information and evidence that the applicant should present and to determine the deadline for their delivery (Modzelewska-Wąchal, in: Skoczny, 2014, p. 1432).

49 As it was rightly emphasized by E. Modzelewska-Wąchal, a failure to take into account a summary application does not deprive the undertaking of the possibility of submitting another summary application, whereby the date and time of submitting the application will be determined by the moment of submitting the last application (Modzelewska-Wąchal, in: Skoczny, 2014, p. 1433).

50 ECN Model Leniency Programme, section 21, p. 6. 
The third procedural aspect emerging from the comparison of the Polish leniency programme with the model one concerns summary applications. Such applications should be supplemented upon the request of a competition authority, only if the authority has decided to initiate antimonopoly proceedings regarding a given agreement. The possibility to file a summary application is provided for in both programmes and is aimed at eliminating negative consequences of the general rule, according to which the submission of a leniency application to one competition authority does not have any effect on other bodies. ${ }^{51}$ The Model Leniency Programme states that the applicant that has or is in the process of filing a leniency application, either for immunity or for a fine reduction, with the European Commission may file summary applications with any national competition authorities which the applicant considers might be 'well placed' to act under the Network Notice. ${ }^{52}$ By contrast, the rules governing the Polish leniency programme limit the possibility of filing a summary application only to cases when an undertaking submits to the European Commission an application for the immunity from fines. ${ }^{53}$

The scope of the situations when an undertaking is entitled to file a summary application within the Polish leniency programme is, therefore, far more limited than in the model as it cannot be used when applying to the European Commission for a fine reduction (see also: Modzelewska-Wąchal in: Skoczny, 2015, p. 1435). Incidentally, it is worth noting that part of the provision of Article 113f paragraph 1 of the ACCP (where it requires that a leniency application is submitted to the European Commission first before submitting a summary application to the UOKiK President) is to a certain extent contradictory to Article $113 f$ paragraph 3 of the ACCP. The latter states that a summary application shall also contain information about applications submitted or to be submitted by the undertaking in other EU Member States or with the European Commission. Taking into consideration this discrepancy and the solution provided for in the ECN Model Leniency Programme, it should be deemed that a summary application may be filed with the UOKiK President also in the case when the applicant is in the process of filing a leniency application with the European Commission (see also: Turno in: Stawicki and Stawicki, 2016, p. 1539).

51 Due to the fact that a leniency application filed in one member state does not have an effect in another member states, it is assumed that filing leniency applications in all member states where the effects of the competition restricting agreement took place increases the chances of the undertaking to benefit from the leniency programme regardless of the competition authority that will examine the case (Modzelewska-Wąchal, in: Skoczny, 2014, p. 1434).

52 ECN Model Leniency Programme, section 24, p. 6.

53 Article 113f paragraph 1 of the ACCP. 
The solution adopted by the Polish legislator provides for the possibility of filing a leniency application not only by the undertaking being a party to the agreement restricting competition but also by a managing person who is liable under Article 6a of the ACCP for allowing the undertaking to infringe the prohibitions referred to in Article 6 paragraph 1 subparagraphs 1-6 of the ACCP or in Article 101 paragraph 1 subparagraphs a-e TFUE. ${ }^{54}$ The provisions on leniency for managing persons raise a few doubts. For instance, the law does not expressly clarify if there is only one common 'immunity queue' for both undertakings and managers (on this doubts see more: Piszcz, 2015b, p. 50-51; Piszcz, 2016, p. 215-216). The ECN Model Leniency Programme concerns only immunity from fines and the reduction of fines imposed onto undertakings. ${ }^{55}$ Simultaneously, however, in the Explanatory Notes, it is indicated that it may also be appropriate to offer protection from individual sanctions to employees and directors of applicants for a reduction of any fine, especially in cases where the law provides the possibility to impose sanctions also on such persons. ${ }^{56}$

Incidentally, it is worth adding that there is also an additional option in Poland - not provided for in the ECN Model Leniency Programme or in the leniency programme used by the European Commission. This option is called the 'leniency plus programme'. It has been introduced to the ACCP by the Amendment Act of 2014, which entered into force on 18 January 2015. The leniency plus programme assumes the possibility of obtaining an additional reduction of the fine imposed on an undertaking which filed an application for immunity from or reduction of fines pursuant to Article 113c paragraph 1 of the ACCP but failed to meet the conditions for immunity. In order to benefit from this programme, the undertaking shall, prior to the issuance of the decision in the case with respect to which it has submitted an application, be the first of the participants in another agreement (with respect to which no antimonopoly proceedings or preliminary proceedings have been instituted yet) to submit an application regarding that other agreement and to submit to the UOKiK President evidence or information referred to in Article 113b paragraph 2 paragraph (a) of the ACCP. Then the UOKiK President:

${ }^{54}$ In accordance with the Article 6a of the ACCP, where an undertaking is found to be in breach of the prohibitions referred to in Article 6 paragraph 1 subparagraphs 1-6 of the Act or in Article 101 paragraph 1 subparagraphs a-e of the TFEU, a managing person, who - in connection with performing his function at the time of the ascertained infringement of the prohibitions concerned - intentionally allowed, through action or omission, infringement of such prohibitions by the undertaking, shall also be subject to liability.

55 ECN Model Leniency Programme Explanatory Notes, section 15, p. 11.

56 ECN Model Leniency Programme Explanatory Notes, section 15, p. 11-12. 
1) in a case with respect to which the following has been submitted the first application - shall reduce the amount of the fine imposed upon that undertaking by $30 \%$ and

2) with respect to an application regarding another agreement - shall grant the undertaking full immunity against fines provided that the undertaking has fulfilled all of the conditions specified in Article 113b of the ACCP (Article 113d paragraph 1 of the ACCP).

The rules governing the leniency plus programme have been the subject of critical commentary (see: Martyniszyn and Bernatt, 2015, p. 11; Semeniuk and Syp, 2013, p. 33-41; Skoczny, 2015, p. 172). Amongst others, it has been emphasized that there is a problem of what the notion 'other agreement' means. It is not clear whether this notion refers to an agreement regarding another market, other parties, another period of time, or not. Moreover, one may find it hard to explain how to calculate the fine in case the applicant discloses two or more 'other agreements' (Piszcz, 2015b, p. 52; Piszcz, 2016, p. 216).

\section{Polish leniency programme and EU legal acts (legislative harmonisation)}

In accordance with Article 3 paragraph 1 subparagraph $b$ of the TFEU, the Union shall have exclusive competence in establishing the competition rules necessary for the functioning of the internal market. However, the application of competition law in the EU by the national competition authorities of its Member States is decentralized. First of all, it is due to the parallel application of EU competition law and national legislation. The second reason for that is Article 3 paragraph 1 of Regulation No 1/2003 which obliges national competition authorities to apply also Article 101 and 102 TFEU in cases when the national competition authority comes to the conclusion that the competition restricting practise or an abuse of a dominant position subject to their antitrust proceedings infringes not only national rules but also rules regarding, respectively, Article 101 or Article 102 TFEU. While applying EU competition law, a national competition authority, in the absence of EU procedural rules, applies national procedural rules in accordance with the notion of national procedural autonomy ${ }^{57}$, and imposes sanctions on the basis of national law.

57 On the procedural autonomy of the Member States see more: Kowalik-Bańczyk, 2012, p. 530-546. 
Looking for the basis for legislative harmonisation of national leniency programmes, it should be noted that under the current legal status, the essential competence rule authorizing the EU legislator to take action in the area of competition law is the provision of Article 103 paragraph 1 TFEU (Kowalik-Bańczyk, 2012, p. 550). It authorizes the Council, on a proposal from the Commission and after consulting the European Parliament, to lay down appropriate regulations or directives to give effect to the principles set out in Articles 101 and 102 TFEU. On the basis of this legal provision, it should be stated that legislative harmonisation of national leniency programmes, by adopting EU regulations or directives, would require stating that such step is necessary to give effect to the principles set out in Articles 101 and 102 TFEU.

So far, the EU legislator has decided to engage in legislative harmonisation regarding leniency programmes only in one single legal act, namely Directive 2014/104/EU of the European Parliament and of the Council of 26 November 2014 on certain rules governing actions for damages under national law for infringements of the competition law provisions of the Member States and of the European Union ${ }^{58}$ (hereinafter; Damages Directive). The Damages Directive sets out rules coordinating the enforcement of competition rules by competition authorities and the enforcement of those rules in damages actions before national courts. ${ }^{59}$ In motive 26 of the preamble of the Damages Directive, it is indicated that leniency programmes are important tools for the public enforcement of EU competition law, as they contribute to the detection and efficient prosecution of, and the imposition of penalties for, the most serious infringements of competition law. Due to the fact that damages actions in cartel cases generally follow on from those decisions, leniency programmes are also important for the effectiveness of actions for damages in cartel cases.

The Damages Directive itself does not concern directly the rules for leniency programmes, and it is limited in this regard only to issues connected to the disclosure of leniency statements included in the file of a competition authority ${ }^{60}$ as well as to ensure that the civil liability of an immunity recipient is limited. ${ }^{61}$ As a consequence, the scope of legislative harmonisation required by the EU legislator in the area of leniency is limited only to follow on issues,

58 OJ L 349, 5.12.2014, p. 1-19.

59 Article 1 paragraph 2 of the Damages Directive.

60 Article 6 paragraph 6 subparagraph a of the Damages Directive obliges Member States to ensure that, for the purpose of actions for damages, national courts cannot at any time order a party or a third party to disclose leniency statements.

61 Article 11 paragraph 4 of the Damages Directive obliges Member States to ensure that an immunity recipient is jointly and severally liable to its direct or indirect purchasers or providers and to other injured parties only where full compensation cannot be obtained from the other undertakings that were involved in the same infringement of competition law. In the scope of evaluation of the legal regulation included in the Damages Directive in the part relating to 
not connected strictly to the rules or procedure of using leniency programmes by national competition authorities. In Poland, the Damages Directive is implemented by the Act of 21 April 2017 on claims for damages caused by the infringements of competition law. ${ }^{62}$ This statute - similarly to the Damages Directive - does not concern any rules regarding the leniency programme itself or the procedure of applying this programme (it is limited only to the issues required by the Damages Directive).

In the remaining scope, the Polish leniency programme has not been legislatively harmonised. ${ }^{63}$ Nevertheless, this situation may change in the near future because legislative harmonisation of national leniency programmes is one of the aims of the proposal for a directive of the European Parliament and of the Council to empower the competition authorities of the Member States to be more effective enforcers and to ensure the proper functioning of the internal market, which was presented on 22 March 2017. Due to the fact that the legislative procedure regarding the proposal of this directive has not been completed yet, which means that the final version of this act is not yet known, in this article the issues arising from this proposal were intentionally omitted because, in the author's opinion, an analysis of the draft act would not be useful for the research covered by this paper.

\section{Impact of EU jurisprudence on the application of the legal provisions on the Polish leniency programme by the national authorities (judicial harmonisation)}

The analysis of the decisions issued by the UOKiK President in the years 2004-2017 in cases where leniency applications were filed lead to the conclusion that the Polish competition authority, in issues regarding the interpretation or application of provisions of law governing the leniency programme, very rarely refers directly to the judgements of EU courts.

The UOKiK President, while interpreting national rules, referred to EU jurisprudence in a case regarding a competition restricting practice, in the form of determining retail resale prices of paints and varnishes produced by Tikkurila Polska S.A., applied by Castorama Polska sp. z o.o. and Praktiker Polska

the leniency programmes see e.g.: Jurkowska-Gomułka, 2015, p. 68-69; Piszcz, 2015, p. 92-94; Bultorac Malnar, 2015, p. 142-149; Gulińska, 2015, p. 168-174.

62 Journal of Law 2017, item 1132.

63 Incidentally, it should be explained that the assessment of the grounds of further legislative harmonisation of national leniency programmes would exceed the scope of this article. Due to this fact, this issue will not be subject to any deeper analysis in this paper. 
sp. $z$ o.o. In the reasons for this decision, the Polish competition authority, when examining whether a leniency applicant met conditions for the immunity from fines, referred in general to European jurisprudence concerning the interpretation of the term 'initiator of the agreement'. However, while doing so, the authority did not refer to any particular judgement in which this term was interpreted. ${ }^{64}$ An analogous situation can be observed in the reasons for the decision issued in the case of an agreement restricting competition on the market of taxi transport in Grudziadz (city in Poland), in the form of establishing directly or indirectly uniform prices of taxi transport services. ${ }^{65}$ Taking into consideration the fact that references to specifically indicated EU judgements are made relatively often in the reasoning of decisions issued by the UOKiK President in cases regarding competition restricting practices, such a laconic reference in the abovementioned cases to unspecified case-law cannot be considered a sufficient sign of the Polish competition authority actually following EU judgements with respect to issues connected to the interpretation and application of the rules governing the Polish leniency programme.

On the other hand, as regards the case-law of Polish courts examining appeals against the decisions of the UOKiK President, it should be stressed that issues related to the interpretation and application of the provisions of the leniency programme are not often the subject of jurisprudential considerations. ${ }^{66}$ This is mainly due to two factors. Firstly, as it was indicated above, in Poland there are not many cases where leniency applications are being filed. Secondly, the issues related to the interpretation and the application of the rules governing the Polish leniency programme may be, in practice, subject to judicial examination only when the UOKiK President in his decision refuses to grant immunity from fines or when the authority reduces the fine imposed on a leniency applicant but the scope of this reduction is challenged by the leniency applicant. If the UOKiK President grants immunity from fines, the benefiting leniency applicant is usually not interested in appealing against such decision. Moreover, other parties to the antimonopoly proceeding, fined by the UOKiK President for the participation in the same agreement

${ }^{64}$ See: the decision of the UOKiK President on 24 May 2010, no. DOK-4/2010, p 141.

65 See: the decision of the UOKiK President on 26 November 2012, no. RBG-410-02/12/ PD, p. 39.

66 The issues related to the interpretation and application of the provisions of the leniency programme have been the subject of judicial deliberations, in particular in the cases regarding the following UOKiK President's decisions: the decision of the UOKiK President on 8 December 2009, no. DOK-7/09, the decision of the UOKiK President on 24 May 2010, no. DOK - 4/2010, the decision of the UOKiK President on 27 December 2012, no. DOK -8/2012, the decision of the UOKiK President on 4 December 2012, no. RBG-30/2012. 
restricting competition, cannot appeal the decision with respect to the part where immunity from fines was granted to another leniency applicant. ${ }^{67}$

\section{Conclusions}

The analysis made in this article leads to the conclusion that the shape of the Polish leniency programme is undoubtedly a result of the Europeanisation process of national competition law.

The comparison of the rules in the ACCP governing the leniency programme with the solutions proposed in the ECN Model Leniency Programme indicated that the Polish legal solution is, in this regard, a result of spontaneous harmonisation. The minimum harmonisation method chosen by the authors of the ECN Model Leniency Programme resulted in significant discrepancies between the Polish system and the model programme regarding, in particular, the scope ratione personae of both solutions. In effect, the Polish leniency programme may encompass entities who infringed the prohibition of agreements restricting competition regardless of the nature of such practice. By contrast, in the ECN Model Leniency Programme, an undertaking may benefit from this programme only if it was part of a cartel. It basically means that the Polish leniency programme includes a broader scope of agreements. There are also discrepancies between both solutions with respect to rules governing immunity from fines and reductions of fines as well as with respect to rules on the application for a marker or making a summary application.

The rules governing the Polish leniency programme have not been directly subject to legislative harmonisation. There are also insufficient grounds for the conclusions that jurisprudential harmonisation took place in the interpretation and application of the provisions of the Polish leniency programme.

In conclusion, it should be emphasized that despite the fact that the EU legislator did not decide to use the mechanism of legislative harmonisation, the shape of the Polish leniency programme is undoubtedly an effect of the process of Europeanisation. The method of harmonisation which was applied resulted in a situation where discrepancies between the national leniency programmes and the programme applied by the European Commission exist. Due to the fact that the effects of one agreement restricting competition may appear on the territory of more than one EU Member State, each discrepancy between their respective leniency programmes may affect the interests of an undertaking in applying for leniency. Nevertheless, discrepancies between the

${ }^{67}$ See: the judgement of Sąd Ochrony Konkurencji i Konsumentów on 28 November 2014, no. XVII AmA 160/11. 
programmes cannot be the only factor explaining the low level of interest in leniency in Poland. While searching for the explanation of the unpopularity of the Polish leniency programme, one more factor should also be taken into consideration and that is the generally low detectability of infringements by the UOKiK President.

\section{Literature}

Banasiński, C., Piontek, E. (ed.). (2009). Ustawa o ochronie konkurencji i konsumentów. Komentarz, Edition 1, Warsaw: LexisNexis.

Bernatt, M., Turno, B. (2015). O potrzebie doskonalenia rozwiązań procesowych w znowelizowanej z dniem 18 stycznia 2015 r. ustawie o ochronie konkurencji i konsumentów. internetowy Kwartalnik Antymonopolowy i Regulacyjny, 2(4), 75-92.

Bultorac Malnar, V. (2015). Access to Documents in Antitrust Litigation - EU and Croatian Perspective. Yearbook of Antitrust and Regulatory Studies, 8(12), 127-160. DOI: 10.7172/1689-9024.YARS.2015.8.12.6.

Frenz, W. (2016). Handbook of EU Competition Law, Springer-Verlag Berlin Heidelberg. DOI: 10.1007/978-3-662-48593-4.

Gulińska, A. (2015). Collecting Evidence Through Access to Competition Authorities' Files - Interplay or potential Conflicts Between Private and Public Enforcement Proceedings?. Yearbook of Antitrust and Regulatory Studies, 8(12), 161-180. DOI: 10.7172/1689-9024.YARS.2015.8.12.7.

Hammond, S.D. (2004). Cornerstones of an Effective Leniency Program. Presented at the ICN Workshop on Leniency Programs, Sydney, November 22-23, 2004. Retrieved from: https://www.justice.gov/atr/file/518156/download (16.05.2018).

Jurkowska-Gomułka, A. (2015). How to Throw the Baby out with the Bath Water. Remarks on the Currently Accepted Scope of Civil Liability for Antitrust Damages. Yearbook of Antitrust and Regulatory Studies, 8(12), 61-78. DOI: 10.7172/1689-9024. YARS.2015.8.12.3.

Kowalik-Bańczyk K. (2012). Prawo do obrony w unijnych postępowaniach antymonopolowych w kierunku unifikacji standardów proceduralnych w Unii Europejskiej, Warsaw: Wolters Kluwer Polska.

Kowalik-Bańczyk, K. (2014). Ways of Harmonising Polish Competition Law with the Competition Law of the EU. Yearbook of Antitrust and Regulatory Studies, 7(9), 141-159.

Król-Bogomilska, M. (2013). Zwalczanie karteli w prawie antymonopolowym i karnym, Warsaw: Wydawnictwo Naukowe Scholar.

Martyniszyn, M. and Bernatt, M. (2015). On Convergence with Hiccups: Recent amendments to Poland's Competition Law. European Competition Law Review, 1, 8-14.

Molski, R. (2009). Polish Antitrust Law in its Fight Against Cartels - Awaiting a Breakthrough. Yearbook of Antitrust and Regulatory Studies, 2(2), 49-76

Piszcz, A. (2013). Osoba zarządzająca w rządowym projekcie ustawy zmieniającej ustawę o ochronie konkurencji i konsumentów. internetowy Kwartalnik Antymonopolowy i Regulacyjny 7(2), 23-30. 
Piszcz, A. (2015a). Piecemeal Harmonisation Through the Damages Directive? Remarks on What Received Too Little Attention in Relation to Private Enforcement of EU Competition Law. Yearbook of Antitrust and Regulatory Studies, 8(12), 79-99, DOI: 10.7172/1689-9024.YARS.2015.8.12.4.

Piszcz, A. (2015b). Nowe elementy regulacji prawnej kar pieniężnych w ustawie o ochronie konkurencji i konsumentów. internetowy Kwartalnik Antymonopolowy i Regulacyjny, 2(4), $42-58$.

Piszcz, A. (2016). A Note on 2015 Developments in Polish Competition Law: Is it Really a Drive Towards the European Model? Yearbook of Antitrust and Regulatory Studies, 9(14), 203-225, DOI: 10.7172/1689-9024.YARS.2016.9.14.10.

Rumak, E. and Sitarek, P. (2009). Polish Leniency Programme and its Intersection with Private Enforcement of Competition Law. Yearbook of Antitrust and Regulatory Studies, 2(2), 99-123.

Semeniuk, P. and Syp, S. (2013). „Wylanie dziecka z kąpielą” - czyli o leniency plus w Polsce. internetowy Kwartalnik Antymonopolowy i Regulacyjny, 7, 31-41.

Sitarek, P. (2014). The Impact of EU Law on a National Competition Authority's Leniency Programme - the Case of Poland. Yearbook of Antitrust and Regulatory Studies, 7(9), 185-216.

Skoczny, T. (ed.). (2014). Ustawa o ochronie konkurencji i konsumentów. Komentarz, edition 2., Warsaw: C.H. Beck.

Skoczny, T. (2015). 2014 Amendment of the Polish Competition and Consumers Protection Act 2007. Yearbook of Antitrust and Regulatory Studies, 8(11), 165-183.

Sołtysiński, S. (2004). Z doświadczeń programu leniency w Brukseli i w Warszawie in: C. Banasiński (ed.). Prawo konkurencji - stan obecny i przewidywane kierunki zmian, Warsaw: Urząd Ochrony Konkurencji i Konsumentów.

Stawicki, A., Stawicki, E. (ed.). (2016). Ustawa o ochronie konkurencji i konsumentów. Komentarz, edition II, Warsaw: Wolters Kluwer Polska.

Turno, B. (2013). Leniency. Program łagodzenia kar pieniężnych w polskim prawie ochrony konkurencji, edition 1., Warsaw: Wolters Kluwer Polska. 